\title{
Role of persistent low-level clouds in mitigating air quality impacts of wintertime cold pool conditions
}

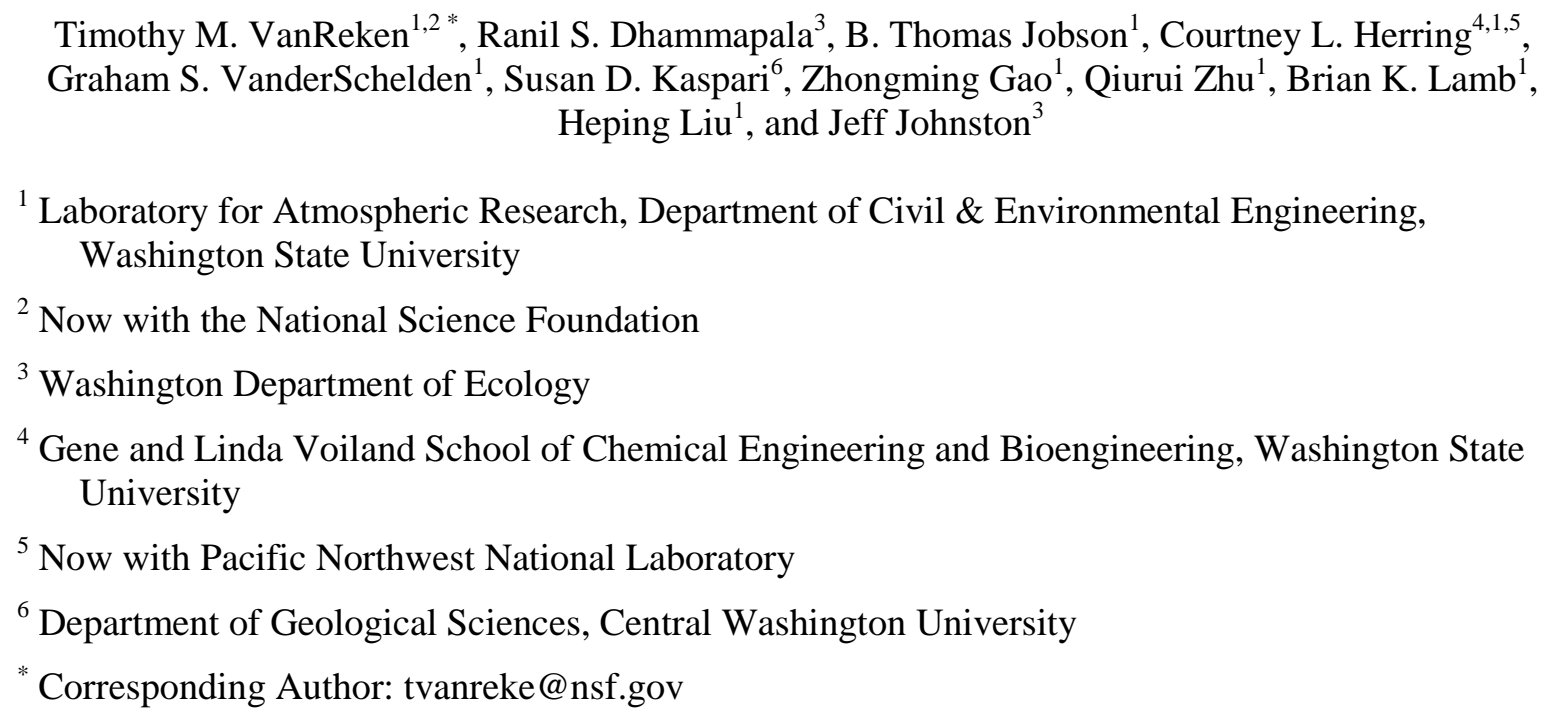

Keywords: Stagnation, Cloud-topped Boundary Layer, Wintertime Air Quality, Aerosol Nitrate

\section{ABSTRACT}

The Yakima Air Wintertime Nitrate Study (YAWNS) was conducted in January 2013 to investigate the drivers of elevated levels of fine particulate matter $\left(\mathrm{PM}_{2.5}\right)$ frequently present in the region during winter stagnation periods. An extended stagnation period occurred during the study. For the first four days of the event, skies were clear and the strong diel variation in air pollution patterns were consistent with the expected effects of strong lowlevel nighttime temperature inversions with moderate mixing during daylight hours. Later in the event a low-level cloud layer formed that persisted over the Yakima Valley for the next seven days while regional conditions remained stagnant. Coincident with the onset of cloud, the levels of all measured primary pollutants, including $\mathrm{CO}_{2}, \mathrm{CO}, \mathrm{NO}_{\mathrm{x}}$, particle number concentration, and black carbon, dropped dramatically and remained low with negligible diel variation for as long as the cloud layer was present. The observed patterns for these air pollutants are consistent with decreased stability and enhanced mixing associated with the cloud-topped boundary layer. Interestingly, levels of secondary pollutants, most notably particulate ammonium nitrate, did not exhibit the same decline. This difference may be due to shifts in the chemical production of secondary pollutants during cloudy conditions, or may merely reflect a further influence of mixing. The results imply that the best strategies for managing wintertime air quality during episodes of persistent cloud are likely different from those needed during clear-sky stagnation events. 


\section{Introduction}

Severe wintertime particulate pollution episodes are a major environmental concern in cooler climates, especially in populated areas with valley topography. Such episodes are typically driven by a combination of increased emissions of particulate material (PM) from burning wood for home heating, increased vehicle emissions from engine cold starts, and reduced ventilation due to unfavorable meteorological conditions (Malek et al., 2006; Silcox et al., 2012; Lareau et al., 2013; Whiteman et al., 2014; Largeron and Staquet, 2016). Managing wintertime air pollution episodes requires different strategies than are employed during summertime photochemical pollution episodes. While the latter have been studied more extensively, the relative lack of understanding of the factors impacting wintertime air quality could potentially lead to ineffective air quality management decisions.

The typical severe wintertime PM episode is associated with stagnant atmospheric conditions that result from a combination of meteorological and topographic factors. The stagnation occurs under a large-scale high-pressure system that leads to subsidence (downward atmospheric motion), and is normally associated with clear skies, cold nights, and low surface wind speeds (Wolyn and McKee, 1989; Whiteman et al., 1999, 2001). During winter when there is reduced solar heating of the surface, these conditions will also be associated with a shallow planetary boundary layer (PBL). At night under clear skies, a strong surface temperature inversion can occur, and this condition can extend through the daylight hours when snow cover is present. The combination of a shallow, stable PBL and minimal horizontal advection can lead to the buildup of high pollutant concentrations, especially when emissions also increase due to activities associated with cold temperatures, such as wood burning and vehicle cold-starts and idling.

The effects of stagnation are exacerbated by valley topography where cold-air pooling can occur (Whiteman et al., 2001, 2008; Lareau et al., 2013; Chachere and Pu, 2016). A cold-air pool forms when surface cooling leads to low-level atmospheric stability while the valley topography inhibits horizontal advection, enhancing the stagnant condition. The result is that persistent cold-air pools can lead to exceptionally high pollution levels. These events have been the focus of several studies. Green et al. (2015) compared trends in several cities in the western United State, and additional targeted studies there have been conducted in the Treasure Valley in Idaho (Kuhns et al., 2003; Stockwell et al., 2003), the Cache Valley in Utah (Malek et al., 2006; Silva et al., 2007), Salt Lake City, Utah (Silcox et al., 2012; Lareau et al., 2013; Whiteman et al., 2014; Holmes et al., 2015), and near Reno, Nevada (Chen et al., 
2012). Outside of the U.S., the effects of cold-air pools on PM levels have been investigated in the Chamonix Valley (Chazette et al., 2005) and the Arve River Valley (Chemel et al., 2016; Largeron and Staquet, 2016) in France, and in Nelson, New Zealand (Grange et al., 2013). Current modeling capabilities have proven inadequate for predicting the severity of the pollution impacts of these events (Zhang et al., 2014; Holmes et al., 2015).

The generalized conceptualization of a stagnation event implies clear-sky conditions, and such conditions have been the primary focus of past studies. However, the existence of cold-air pools can also lead to a different meteorological condition, wherein a persistent lowlevel cloud layer forms. The presence of clouds inhibits surface daytime warming and nighttime cooling and thus disrupts the typical diel pattern in boundary layer mixing (Wolyn and McKee, 1989; Whiteman et al., 2001; Zhong et al., 2001). These dynamics have been described previously (Pataki et al., 2005), but they have proven difficult to capture in meteorological models and thus remain challenging to forecast (Reeves and Stensrud, 2009; Reeves et al., 2011; Hughes et al., 2015; Pu et al., 2016). The specific impacts of persistent clouds on air pollution within valley cold air pools have not been thoroughly examined.

In two recent studies, air quality has been measured during periods of persistent lowlevel cloud within cold air pools, revealing notably different characteristics than are observed during clear sky stagnation conditions (Wallace et al., 2012; Mwaniki et al., 2014). Unlike the elevated air pollution observed during nighttime surface inversions under cold clear sky conditions, during these cloudy events there was instead a significant decline in most air pollutants, and almost no diel variability. This phenomenon was first noted in the Treasure Valley in Idaho in the United States during the winter of 2008-09, when the area became persistently foggy during a week-long stagnation period.

Here we present a more thorough examination of the phenomenon using observations made in Washington State's upper Yakima Valley in January 2013, as part of the Yakima Air Wintertime Nitrate Study (YAWNS). Although Yakima is compliant with the United States federal 24-hour fine particulate material $\left(\mathrm{PM}_{2.5}\right)$ standard, monitored wintertime $\mathrm{PM}_{2.5}$ concentrations frequently approach the standard. Yakima is unusual within the region in that a significant fraction of the wintertime $\mathrm{PM}_{2.5}$ is comprised of particulate nitrate; YAWNS was commissioned by the Washington State Department of Ecology to better understand conditions leading to elevated wintertime aerosol nitrate. An extended regional stagnation period occurred during the study, beginning on 12 January, leading to the formation of a cold pool within the valley. Clear skies characterized the first few days of the period, but then a 
103

104

105

106

107

108

109

110

111

112

113

114

115

116

117

118

119

120

121

122

123

124

125

126

127

128

129

130

131

132

133

cloud layer formed over the Yakima valley that persisted for the next seven days. We present here a detailed analysis of the air quality characteristics for the clear and cloudy stagnation periods, relating the meteorological conditions to observed changes in the trace gas and particulate pollutants.

\section{Study Design}

\subsection{Site Description}

The YAWNS observations were made from 5 to 27 January 2013, in Yakima, Washington in the United States (Lat: $46.6^{\circ} \mathrm{N}$, Lon: $120.5^{\circ} \mathrm{W}$ ). Yakima is a small city (population 93,101, estimated 2012) located within the Upper Yakima Valley. The valley is bounded by the Cascade Mountains to the immediate west, and by east-west ridges to the north and south that eventually merge several kilometers to the east (Figure S1). The topography forms an enclosed basin at the surface that restricts horizontal air flow within the valley. Yakima has a semi-arid climate due largely to it location in the rain shadow of the Cascade Mountains. January is its second wettest month (after December), with $29.0 \mathrm{~mm}$ of precipitation falling on average (1981-2010 mean). Mean daily high and low temperatures during January are 3.7 and $-4.6{ }^{\circ} \mathrm{C}$, respectively, making it the second coldest month of the year on average (again after December) (NOAA NOWData, 2013).

The Washington State University Mobile Atmospheric Chemistry Laboratory (MACL) was deployed for the study to the campus of Yakima Valley Community College (YVCC) (Lat: $46.58854^{\circ}$, Lon: $120.5283^{\circ} \mathrm{W}$, Elev. $327 \mathrm{~m}$ ), located in a medium-density mixed residential and commercial neighborhood approximately $1 \mathrm{~km}$ west of the urban center. There were major surface streets approximately $150 \mathrm{~m}$ west and $400 \mathrm{~m}$ south of the site. In the immediate vicinity, there was little vehicle traffic except for small amounts of student parking. Significant amounts of wood smoke were emitted in the neighborhoods near the sampling site due to use of wood fuels for wintertime home heating (VanderSchelden et al., 2017).

\subsection{Measurements}

The MACL trailer provided a temperature-controlled environment for operating the instrumentation during the study. A10-m crank-up tower mounted on the trailer elevated sensors and sampling inlets above the immediate surroundings. For YAWNS, the primary trace gas sampling line was mounted at $10 \mathrm{~m}$, a heated aerosol sampling inlet was mounted at 
$1349 \mathrm{~m}$, and a dedicated $\mathrm{NO}_{\mathrm{x}} / \mathrm{NO}_{\mathrm{y}}$ inlet line was located at $8 \mathrm{~m}$ above ground level. A full discussion of the MACL facility and the instrumentation used during the YAWNS study can be found in the project report (Washington Department of Ecology, 2014); those measurements used for the present analysis are briefly described here. Most instruments reported data at time intervals of one minute or less. For our analysis, all data are averaged to 30 minutes.

\subsubsection{Trace Gases}

Sample air for the most of the trace-gas instrumentation was supplied by a common

142 line, a $1.2 \mathrm{~cm}$ outer diameter PFA tube that was attached to the tower at a height of

143 approximately $10 \mathrm{~m}$. Ambient air was drawn through the sample line into the MACL at $30 \mathrm{~L}$

$144 \mathrm{~min}^{-1}$, and individual instruments sub-sampled from this common inlet. Instruments were

145 protected from particle contamination by in-line Teflon membrane filters. As previously

146 described by Wallace et al. (2012), the $\mathrm{NO}_{\mathrm{x}} / \mathrm{NO}_{\mathrm{y}}$ analyzer had its own inlet system mounted

147 to the metrological tower approximately $8 \mathrm{~m}$ above ground level.

$\mathrm{NO}, \mathrm{NO}_{2}$, and $\mathrm{NO}_{\mathrm{y}}$ were measured using a two-channel chemiluminescence $\mathrm{NO}$

149 detector (Air Quality Design). $\mathrm{NO}_{\mathrm{y}}$ was measured continuously on one channel by conversion

150 to NO with a molybdenum oxide catalytic converter. The other channel measured NO for 30

151 seconds then $\mathrm{NO}_{\mathrm{x}}\left(\mathrm{NO}+\mathrm{NO}_{2}\right)$ for 30 seconds in an alternating cycle. During the $\mathrm{NO}_{\mathrm{x}}$ measurement, $\mathrm{NO}_{2}$ was photolyzed to $\mathrm{NO}$ using a blue light converter, and the difference between the measured $\mathrm{NO}_{\mathrm{x}}$ and $\mathrm{NO}$ was reported as $\mathrm{NO}_{2}$. Carbon monoxide $(\mathrm{CO})$ was measured using a vacuum UV florescence instrument (Aerolaser GmbH, Germany). The instrument allows fast response and sensitive measurements of $\mathrm{CO}$; the response time is approximately 1 second and the detection limits is approximately 50 pptv. Carbon dioxide was measured by a LiCor 840A analyzer. Ozone was measured by UV absorption using a Daisibi 1008 monitor.

VOC measurements were made using a proton-transfer-reaction mass spectrometer

160 (PTR-MS, Ionicon Analytik, GmbH, Austria). The PTR-MS continuously measures organics 161 in air by chemical ionization using $\mathrm{H}_{3} \mathrm{O}^{+}$as a proton transfer reagent ion (Lindinger et al., 162 1998). Compounds of interest in urban atmospheres that can be measured with this approach 163 include aromatic compounds such as benzene and toluene, simple alcohols (methanol and 164 ethanol) and aldehydes (formaldehyde, acetaldehyde). The instrument is insensitive to small 165 alkanes, acetylene, and ethylene. For monoaromatic compounds that have geometric 
166 isomers, the sum of all contributing compounds is reported. For example, the sum of xylene isomers and ethylbenzene are reported collectively as the $\mathrm{C}_{2}$-benzenes.

\subsubsection{Particles}

Particulate material was sampled from the tower through a $12 \mathrm{~m}$ long, $1.2 \mathrm{~cm}$ outer diameter heated copper tube with an inlet approximately $9 \mathrm{~m}$ above ground level. The heated inlet was temperature-controlled at $10{ }^{\circ} \mathrm{C}$ and the aerosol was dried using a Nafion dryer before distribution to the sampling instrumentation. Total flow through the aerosol inlet line was $4 \mathrm{~L} \mathrm{~min}^{-1}$. The total particle number concentration was monitored with a TSI Model 3776 condensation particle counter.

The composition of the non-refractory submicron particulate material was measured using an Aerodyne high-resolution time-of-flight aerosol mass spectrometer (HR-AMS)

177 (DeCarlo et al., 2006; Canagaratna et al., 2007). During YAWNS, the HR-AMS was operated in V-mode with a 2-minute averaging interval; only mass spectral (MS-mode) data are used in this analysis. The instrument's vaporizer was set to $600{ }^{\circ} \mathrm{C}$, and flow, velocity, and ionization efficiency (IE) calibrations were performed following standard procedures. The measured $\mathrm{m} / \mathrm{z}$ range was $12-673$ and the average resolutions were 3400,3700 , and 4000 at $\mathrm{m} / \mathrm{z} 28,32$, and 184, respectively. A collection efficiency (CE) of unity was used here for all

183 HR-AMS data, based on strong correlation to the TEOM $\mathrm{PM}_{2.5}$ measurements collected at a nearby location. All data were analyzed using standard AMS software (SQUIRREL v1.52G, PIKA v1.12G) (Sueper, 2010). HR-AMS ions were fit between m/z 12-190 so that the residuals of the difference spectrum were $<5 \%$. The elemental ratio of oxygen to carbon in

187 the organic aerosol component was calculated to assess the degree of oxidation (Canagaratna et al., 2015).

Black carbon (BC) mass in individual particles between $\sim 80-650 \mathrm{~nm}$ was measured

190 using a Single Particle Soot Photometer (SP2) (Schwarz et al., 2006). The SP2 was adjusted

191 following the recommendations of Laborde et al. (2012) and the incandescence signal was calibrated using fullerene soot particles (Alpha Aesar; \#L20W054) that were size selected using a differential mobility analyzer. Data analysis was conducted using the Paul Scherrer Institut Toolkit (Droplet Measurement Technologies, 2013). 


\subsubsection{Meteorology}

Standard meteorological parameters (temperature, pressure, humidity, wind speed and direction, and precipitation) were measured via a weather station (Vaisala WXT510) mounted atop the MACL trailer's sampling tower. Atmospheric PBL heights and cloud base heights were detected using a ceilometer (model CL31, Vaisala) located on the trailer roof. This instrument measures the optical backscatter intensity of light emitted in the near-infrared (wavelength=910 nm) up to 4,500 $\mathrm{m}$ above ground level with a vertical resolution of $10 \mathrm{~m}$. Structures present in the backscatter retrieval (up to three cloud base heights and three PBL heights) were identified using the Vaisala PBL height algorithm (version 3.5), based on the gradient method (Vaisala, Inc., 2010).

Surface energy fluxes were measured using two eddy covariance systems installed at 2.12 and $4.17 \mathrm{~m}$ above ground level on a 6-m tall aluminum tower. Each eddy covariance system consisted of a three-dimensional sonic anemometer (CSAT3, Campbell Scientific, Inc.) and an open-path carbon dioxide/water vapor $\left(\mathrm{CO}_{2} / \mathrm{H}_{2} \mathrm{O}\right)$ infrared gas analyzer (IRGA; model LI 7500a, LI-COR, Inc.). Sensor signals from the eddy covariance systems were recorded at $10 \mathrm{~Hz}$ using a datalogger (model CR5000, Campbell Scientific, Inc.). The $10 \mathrm{~Hz}$ raw time-series data collected in this study were processed and corrected to obtain eddy covariance fluxes using standard approaches. These procedures have been described in detail in the project report (Washington Department of Ecology, 2014).

\section{Results}

\subsection{Air Quality During YAWNS}

During the YAWNS study period in January 2013, the United States 24-hr $\mathrm{PM}_{2.5}$ ambient air quality standard of $35 \mu \mathrm{g} \mathrm{m}^{-3}$ was exceeded in Yakima on two days, 15 and 16 January, with concentrations approaching the standard on 25 January as well. Figure 1 shows the $\mathrm{PM}_{2.5}$ time series for all of January 2013 at both the Yakima $4^{\text {th }}$ Avenue monitoring station operated by the Yakima Regional Clean Air Agency (YRCAA), and the Toppenish monitoring station operated by the Yakama Tribal Nation. Toppenish is located in the Lower Yakima Valley, approximately $35 \mathrm{~km}$ to the southeast of Yakima. The figure also indicates the periods when regulatory burn bans were implemented in the region in response to observed or projected episodes of poor air quality. During a Stage 1 burn ban, the Washington Department of Ecology prohibits outdoor and forest burning and the use of 
226 uncertified wood stoves or fireplaces. During a more stringent Stage 2 ban, all wood burning is prohibited, unless it is the residence's or commercial establishment's sole source of adequate heat (Revised Code of Washington, 70.94.473). A brief Stage 2 ban was implemented on 7 January but was removed the following day when a frontal passage

230 cleaned out the valley. A Stage 1 burn ban was implemented on 14 January in response to the

231 buildup of pollution at the start of the stagnation period. Burn bans remained in effect until 29

232 January, changing between Stage 1 and Stage 2. The bans covered all areas overseen by

233 YRCAA in the Upper and Lower Yakima Valleys.

\section{3.2. Regional Stagnation Period}

A temporal minimum in surface pressure accompanied a frontal passage through the

236 region on 8 January, which advected in less polluted air and thus caused a rapid decrease in

$237 \mathrm{PM}_{2.5}$ levels (Figure 1). Over the following several days, surface pressure gradually increased

238 under generally clear conditions. Beginning on 12 January, the surface meteorological

239 conditions in Yakima exhibited characteristics consistent with a typical clear-sky stagnation

240 event. Pressure was elevated (>1,020 mb), skies were clear, and winds remained below $2.5 \mathrm{~m}$

$241 \mathrm{~s}^{-1}$. Mixing heights were less than $500 \mathrm{~m}$ above ground level (AGL) during daytime and as

242 low as $100 \mathrm{~m}$ AGL at night. Surface temperature and relative humidity showed strong diel

243 cycles typical of such conditions (Figure 2). By 14 January, the nearest twice-daily

244 temperature soundings (at Salem, Oregon, Quillayute, Washington, and Spokane,

245 Washington, all in the United States) were consistently showing strong subsidence inversions

246 with dry air above the surface layer, indicating a significant regional stagnation event (Figure

247 S2) (University of Wyoming, 2015). 


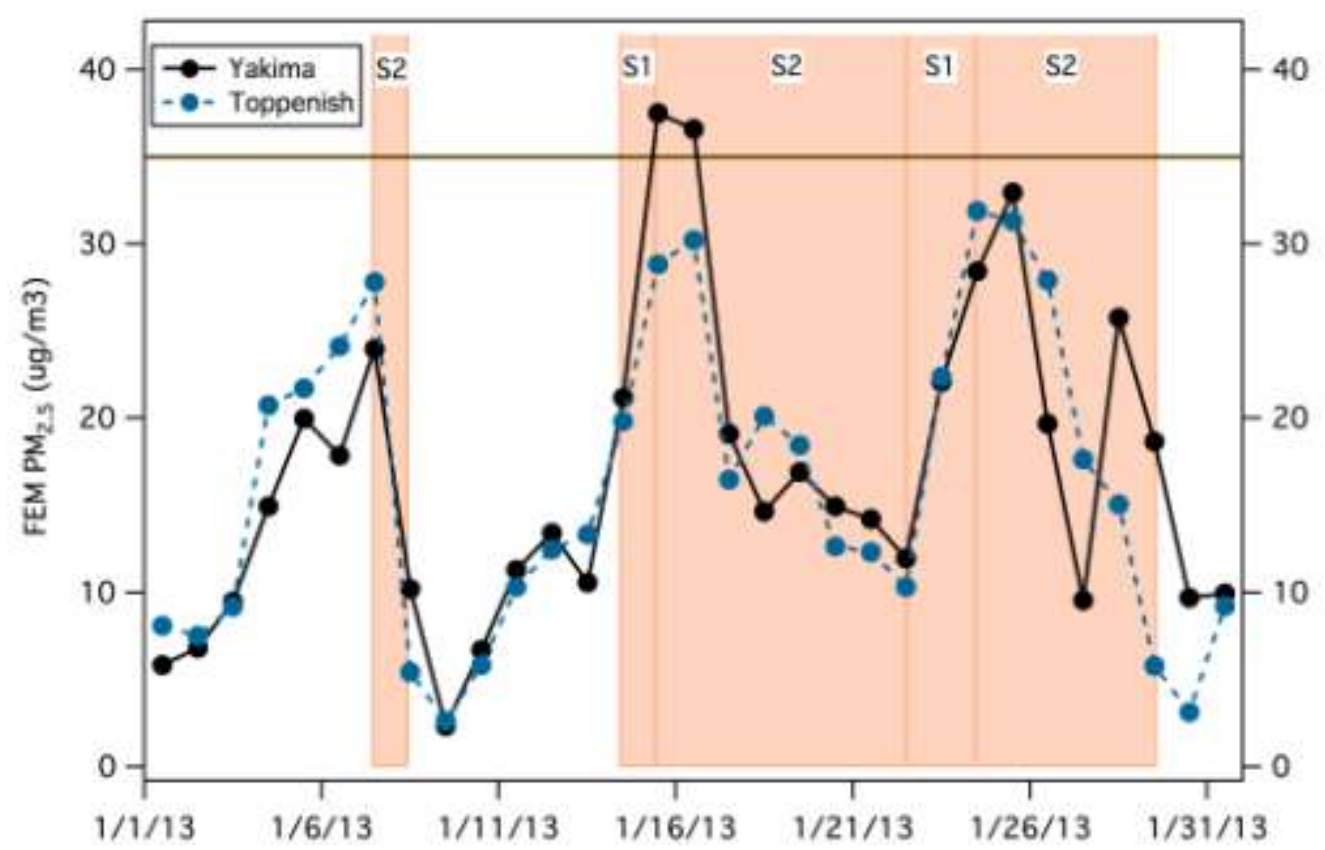

Figure 1. Time series of daily (24-hr) $\mathrm{PM}_{2.5}$ levels measured at the Yakima and Toppenish monitoring sites during January 2013. Measurements were made using a Federal Equivalent Method (FEM), meaning that the method is approved by the United States Environmental Protection Agency for regulatory monitoring. Shaded areas indicate Stage 1 (S1) and Stage 2 (S2) burn bans, as labeled. The horizontal line indicates the 24-hr National Ambient Air Quality Standard for $\mathrm{PM}_{2.5}$.
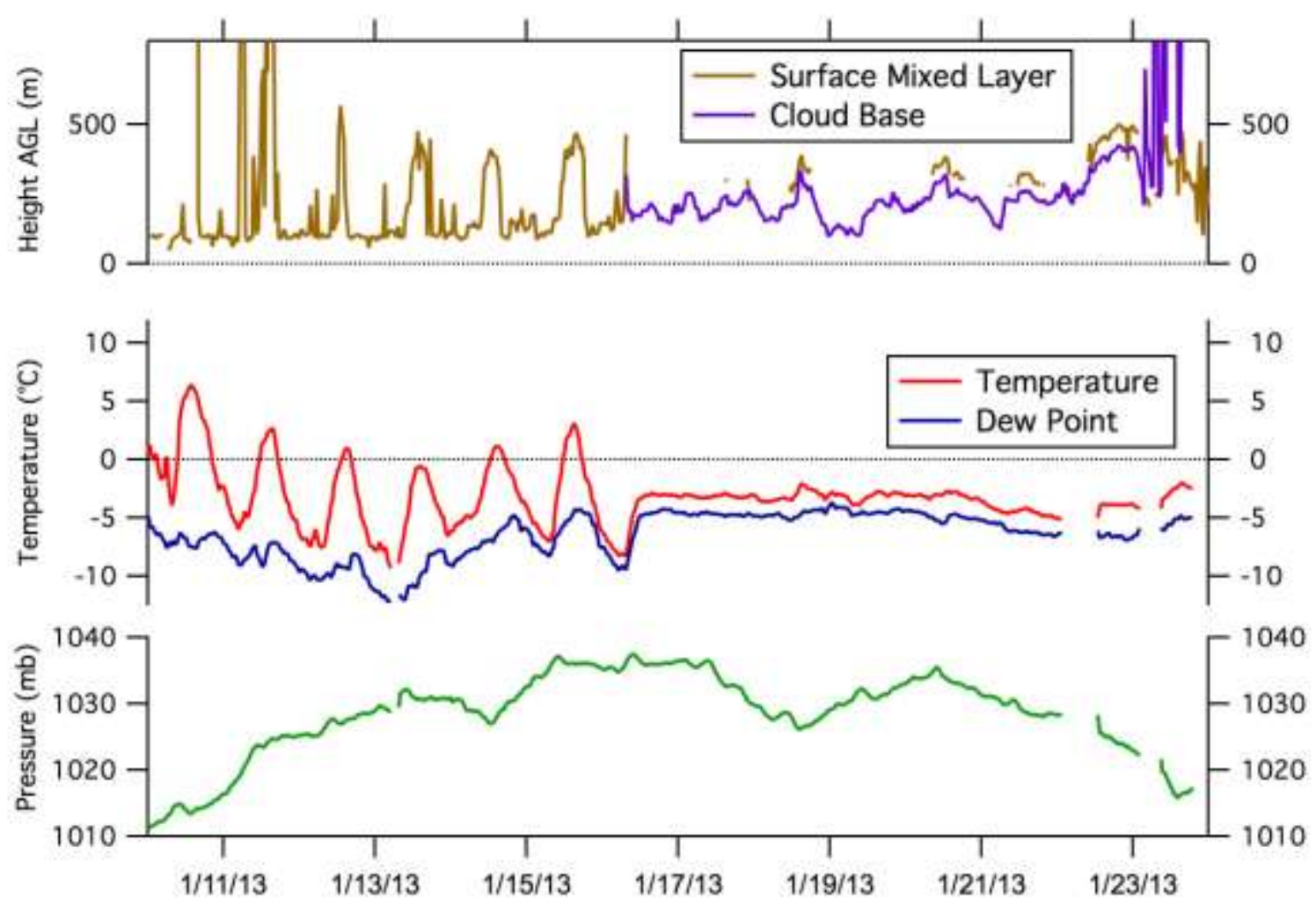

Figure 2. YAWNS time series for meteorological conditions at Yakima. Pressure has been corrected to sea level equivalent. 
Beginning on the morning of 16 January, widespread persistent cloud layer covered the Yakima Valley and much of the Columbia Basin, lasting until 23 January. Though the strong subsidence inversion with dry air aloft remained in place, within the Yakima Valley cloud cover was near complete with cloud base at $500 \mathrm{~m}$ or lower. There was no snow cover during the period. Temperature and RH remained almost constant. Wind speeds (Figure S3) were low during the clear sky stagnation period, averaging $0.9 \mathrm{~m} \mathrm{~s}^{-1}$ (range: $0.3-2.5 \mathrm{~m} \mathrm{~s}^{-1}, 30$ min averages); they were only slightly higher during the cloudy period, averaging $1.2 \mathrm{~m} \mathrm{~s}^{-1}$ (range: $0.4-2.2 \mathrm{~m} \mathrm{~s}^{-1}$ ). The breakup of the cloud layer on 23 January coincided with a decrease in pressure, an increase in surface mixed layer depth, and the conclusion of the stagnation event.

\section{3. $\quad$ Air Quality during the Stagnation Period}

As shown in Figure 1, the initiation of the stagnation period on 12 January coincided with a progressive increase in $\mathrm{PM}_{2.5}$ concentration, with a diel cycle superimposed. The increasing PM pollution led to a Stage 1 burn ban being implemented on 14 January; the ban severity was increased to Stage 2 the following day. $\mathrm{PM}_{2.5}$ levels continued to increase overnight, finally reaching a peak hourly value of $54 \mu \mathrm{g} \mathrm{m}^{-3}$ at the Yakima $4^{\text {th }}$ Avenue monitoring station on the early morning of 16 January. From that peak, the concentration then dropped down to $26 \mu \mathrm{g} \mathrm{m}^{-3}$ by noon, with the steepest drop occurring between 11:00 and noon (all times local). The onset of persistent low clouds in the area occurred around 8:00 that morning.

Based on the unspeciated $\mathrm{PM}_{2.5}$ and meteorological data alone (which air quality managers have access to in near-real time), it would be reasonable to attribute the decrease of $\mathrm{PM}_{2.5}$ to increased wet scavenging within the newly formed cloud, and perhaps the breakup of the nocturnal surface inversion. Additional reductions might be ascribed to good community compliance with the Stage 2 burn ban imposed in the region on the evening of 15 January. While these conclusions would be reasonable in the context of limited data availability, the richness of the YAWNS observations demonstrate that a more significant modification to the local air quality conditions occurred on the morning of 16 January.

The time series for several measured trace gases are shown in Figure 3, including carbon dioxide $\left(\mathrm{CO}_{2}\right)$, carbon monoxide $(\mathrm{CO})$, nitrogen oxides $\left(\mathrm{NO}_{\mathrm{x}}\right)$, and $\mathrm{C}_{2}$-benzenes. As the near-surface stagnation period began to set in under clear conditions on 12 January, the temporal variation for observed gas-phase pollutants followed the typical pattern: elevated 
concentrations during the night, peak levels during the early morning and late evening traffic and wood burning periods, with some reductions during the day. These features become prominent beginning on 14 January, coinciding with the establishment of the strong regionalscale subsidence inversion and low wind speeds, which further inhibited dispersion of valley emissions. Particle number concentration $\left(N_{\text {tot }}\right)$ and $\mathrm{PM}_{2.5}$, also shown in Figure 3, followed similar cycles as the trace gas pollutants during the clear-sky stagnation period.

297
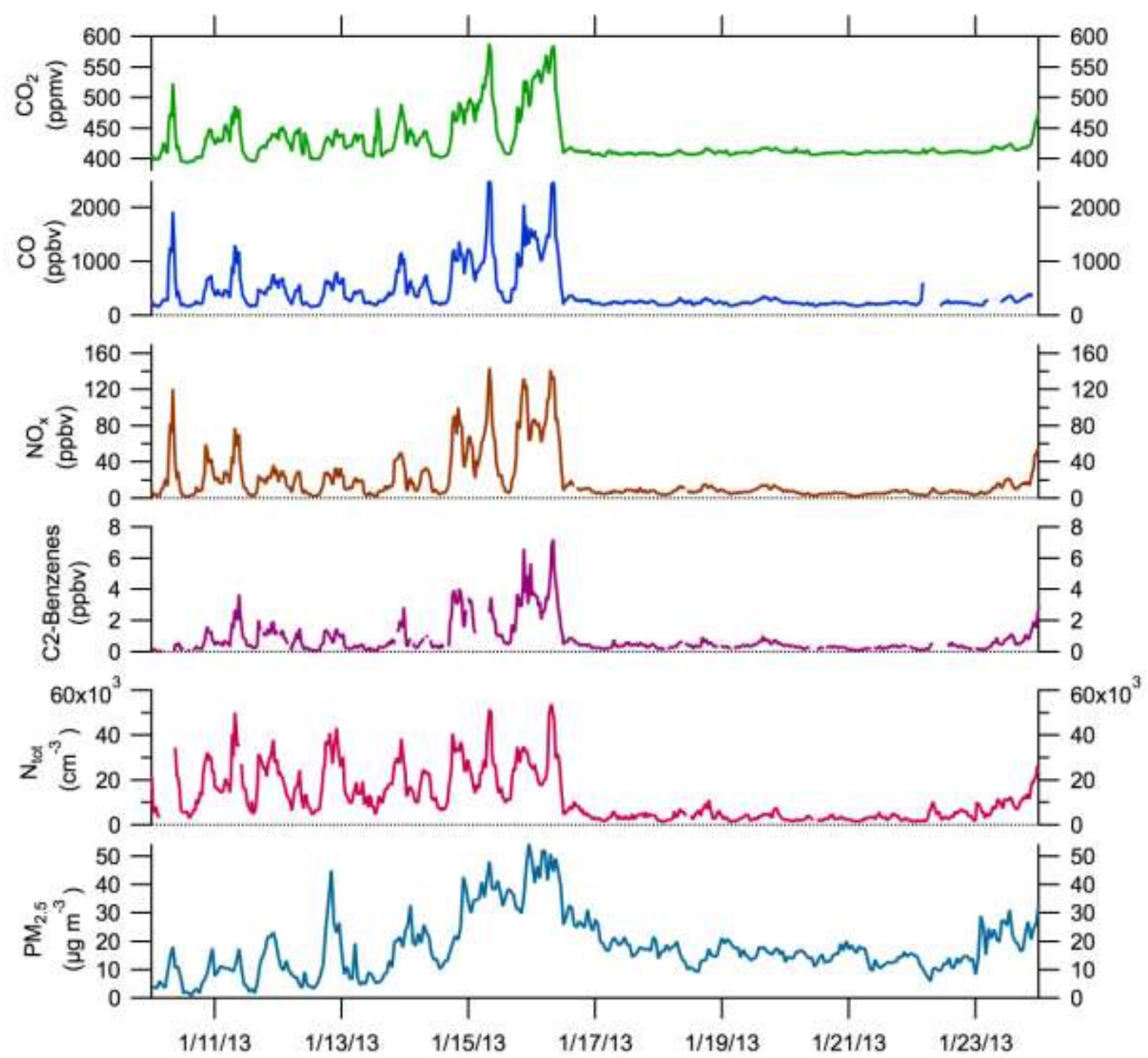

Figure 3. Times series for trace gas and total particle number concentrations during YAWNS. Starting at the top, data are presented for carbon dioxide $\left(\mathrm{CO}_{2}\right)$, carbon monoxide $(\mathrm{CO})$, nitrogen oxides $\left(\mathrm{NO}_{\mathrm{x}}\right), \mathrm{C}_{2}$-benzenes, and total particle number $\left(N_{\text {tot }}\right)$. Also included is the $\mathrm{PM}_{2.5}$ concentration from the Yakima $4^{\text {th }}$ Street monitoring site for comparison. 

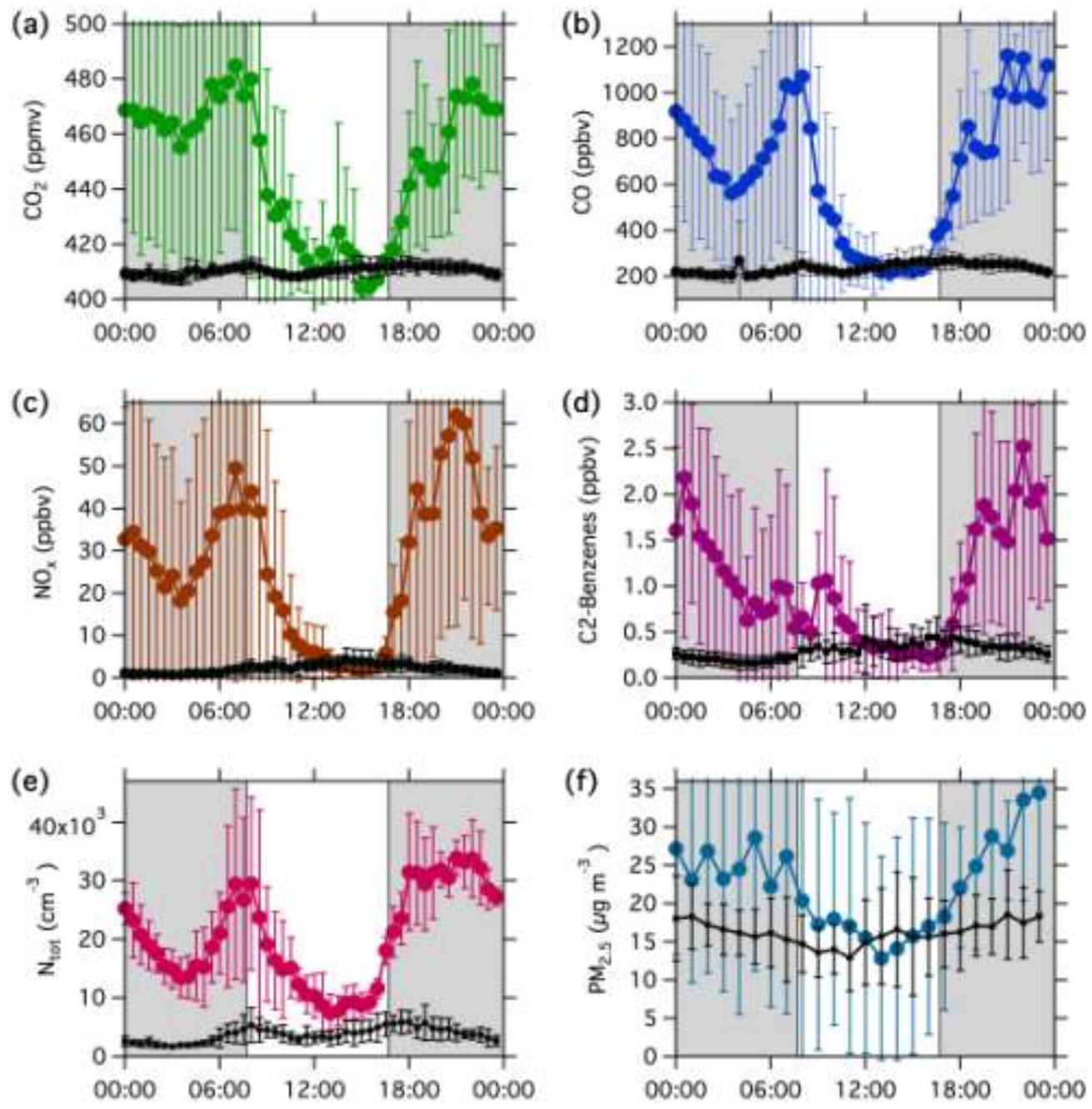

Figure 4. Diel mean cycles for the same parameters shown in Figure 3. In each panel, colored traces represent clear-sky stagnation data (00:00 12 January - 07:00 16 January), and black traces represent the cloudy period (12:00, 16 January - 00:00, 23 January). Vertical bars represent \pm 1 standard deviation of the data to indicate variability. In the clear-sky stagnation data, the increasing day-to-day trend in primary pollutant concentrations is a major contributor to the overall variability. Shaded areas represent nighttime. Y-axis scales differ between panels.

The diel patterns of these pollutants for the clear-sky portion of the stagnation period are shown as the colored traces in Figure 4. The clear-sky results include all data collected from 00:00 12 January to 07:00 16 January, in 30-minute intervals. Similar concentration patterns are observed for each of the pollutants expected to be driven predominantly by combustion - $\mathrm{CO}_{2}, \mathrm{CO}, \mathrm{NO}_{\mathrm{x}}$, and $N_{\text {tot }}$ (Figure 4, panels a, b, c, and e, respectively). Each daily cycle increases from an initial relative minimum along with the typical increase in emissions from morning activity. At first these emissions remain near the surface within the shallow stable nocturnal boundary layer (mixing layer depth $\sim 100 \mathrm{~m}$, Figure 1), but after sunrise, as the mixing depth increases to $\sim 400 \mathrm{~m}$, concentrations show a corresponding decrease due to increased vertical dilution. Concentrations for each of these combustion- 
dominated primary pollutants reach minima around noon and stabilize at those levels until sunset around 17:00. After sunset, emissions increase again due to the evening rush hour and increased home fuel combustion, while simultaneously the shallow nocturnal boundary layer is reestablished and becomes strongly stable, causing further buildup of pollution levels. This buildup continues until emissions decrease in the late evening.

The combined $\mathrm{C}_{2}$-benzenes (Figure $4 \mathrm{~d}$ ) exhibit a somewhat different diel pattern than the other trace gas species shown in Figure 4. While its morning increase is less clearly defined, the effects of mixing layer dynamics on the $\mathrm{C}_{2}$-benzenes diel profile are similar to the other species, with relatively lower levels found during afternoon in daylight, and then increases once the sun sets and the shallow, stable boundary layer takes hold overnight. Similar patterns were observed for other VOCs, including benzene, formaldehyde, and aceataldehyde (Figure S4).

There was a marked change in the observed trace gas and particulate pollution patterns after the onset of persistent low cloud on 16 January. The time series (Figure 3) shows all of the trace gases and $N_{\text {tot }}$ dropping rapidly during the late morning of that day, and then remaining very stable at those low levels continuously for several days. Only when the cloud layer broke on 23 January did the trace gases and $N_{\text {tot }}$ begin to increase again. The persistence of the low concentrations observed during the cloudy period is apparent in diel cycles (Figure 4, black traces), which include all data collected from noon on 16 January until midnight on 23 January. While in most cases there is evidence of small diel patterns during the cloudy period, particularly the morning and evening rush hours, it is nonetheless clear that the dominant pattern is for the pollutant concentrations to vary only minimally throughout the day. These observed persistent concentrations for each pollutant are very close to the levels found at the mid-afternoon minima during the clear-sky stagnation period, suggesting similar dispersion rates of urban emissions.

The sharp shift in the diel pattern of these pollutants occurred despite the regional stagnation event continuing as before. However, other YAWNS measurements reveal that the near-surface mixing conditions changed with the onset of cloud, suggesting a likely cause for the observed low pollutant levels. The Monin-Obukhov stability parameter (Monin and Obukhov, 1954) was calculated for the YAWNS site using data from the 6-m eddy flux tower (Figure 5). Because eddy flux data were not available until late on 14 January, the stability parameter could not be calculated for periods before that time. Positive values of the stability parameter indicate stable atmospheric conditions, while negative values, even very small 
353

354

355

356

357

358

359

360

361

362

ones, indicate periods of atmospheric instability with increased mixing. Figure 5 shows that the atmosphere was indeed stable at night during the clear sky stagnation period, indicated by the positive stability parameter values on the nights of 14 and 15 January. The surface then becomes unstable each morning- the stability parameter had negative values on the mornings of 15 and 16 January, with particularly unstable conditions under clear sky conditions on the morning of 15 January. In marked contrast, once the onset of cloud occurs, there are no longer any periods of stable conditions at the surface for the entire remainder of the regional stagnation event. Despite the continuation of the regional-scale subsidence inversions, neutral or slightly unstable conditions prevailed at the surface in Yakima for the entire week of 16-23 January.

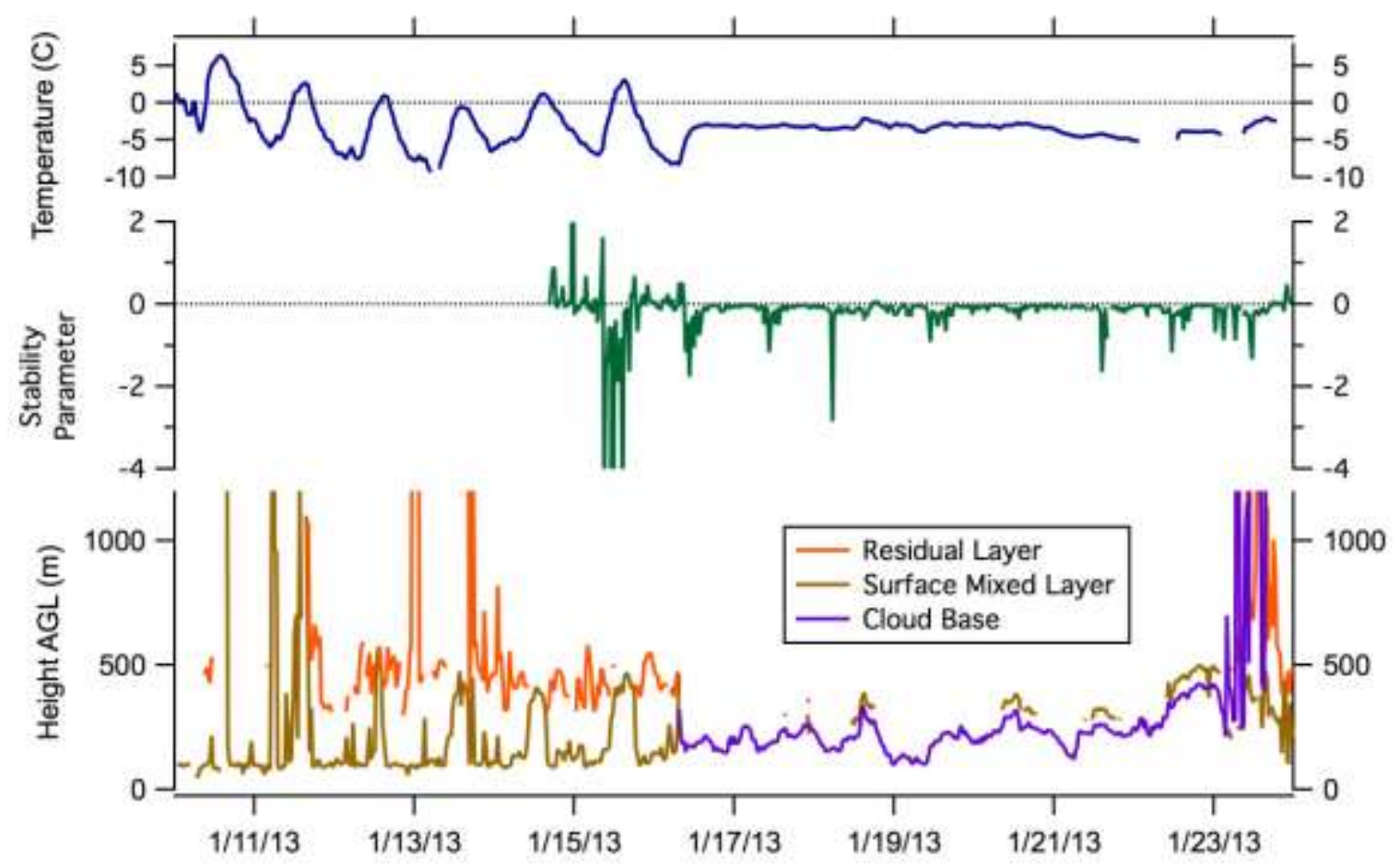

Figure 5. Time series for the stability parameter, calculated using eddy flux measurements. Also included again for comparison are measurements of temperature and observations from the ceilometer. Eddy flux data were only available beginning late on 14 January; the stability parameter could not be calculated for periods before this time.

The temporal and diel cycles for $\mathrm{PM}_{2.5}$ exhibit a less regular pattern during the stagnation period, both before and after the onset of cloud. In the time series (Figure 3, bottom panel, as well as Figure 1), the pattern for $\mathrm{PM}_{2.5}$ suggests a general increasing trend during the clear-sky stagnation period, with a diel pattern superimposed. At the onset of cloudy conditions on 16 January, the $\mathrm{PM}_{2.5}$ concentration decreases from a peak of $54 \mu \mathrm{g} \mathrm{m}^{-3}$ to $26 \mu \mathrm{g} \mathrm{m}^{-3}$, but the decline is not as sharp as those observed for other pollutants. 
374 Concentrations continued to trend downward over the next few days, but never reached the

375

376

377

378

379

380

381

382

383

384

385

386

387

low daytime levels of 5-10 $\mu \mathrm{g} \mathrm{m}^{-3}$ observed during the early part of the clear-sky stagnation period. The diel pattern for $\mathrm{PM}_{2.5}$ (Figure 4f) suggests some influence by the same dynamic factors that affected the other pollutants. Under clear sky conditions there was a similar pattern of pollutant buildup overnight followed by daytime dilution, while during the cloudy period this cycle was much less pronounced. However, the $\mathrm{PM}_{2.5}$ pattern differs from other pollutants in that it lacks a clear morning rush hour peak.

An examination of the aerosol composition across during the stagnation period helps explain the complex temporal pattern observed for $\mathrm{PM}_{2.5}$. Figure 6 shows the time series for particulate ammonium $\left(\mathrm{NH}_{4}{ }^{+}\right)$, sulfate $\left(\mathrm{SO}_{4}{ }^{2-}\right)$, nitrate $\left(\mathrm{NO}_{3}{ }^{-}\right)$, and organic material $(\mathrm{Org})$ as measured by the HR-AMS, and the black carbon (BC) concentration from the SP2. The oxygen to carbon elemental ratio (O:C ratio) for Org is also included, as an indication of the degree of oxidation within the organic aerosol material. Diel plots for these same parameters are shown in Figure 7.
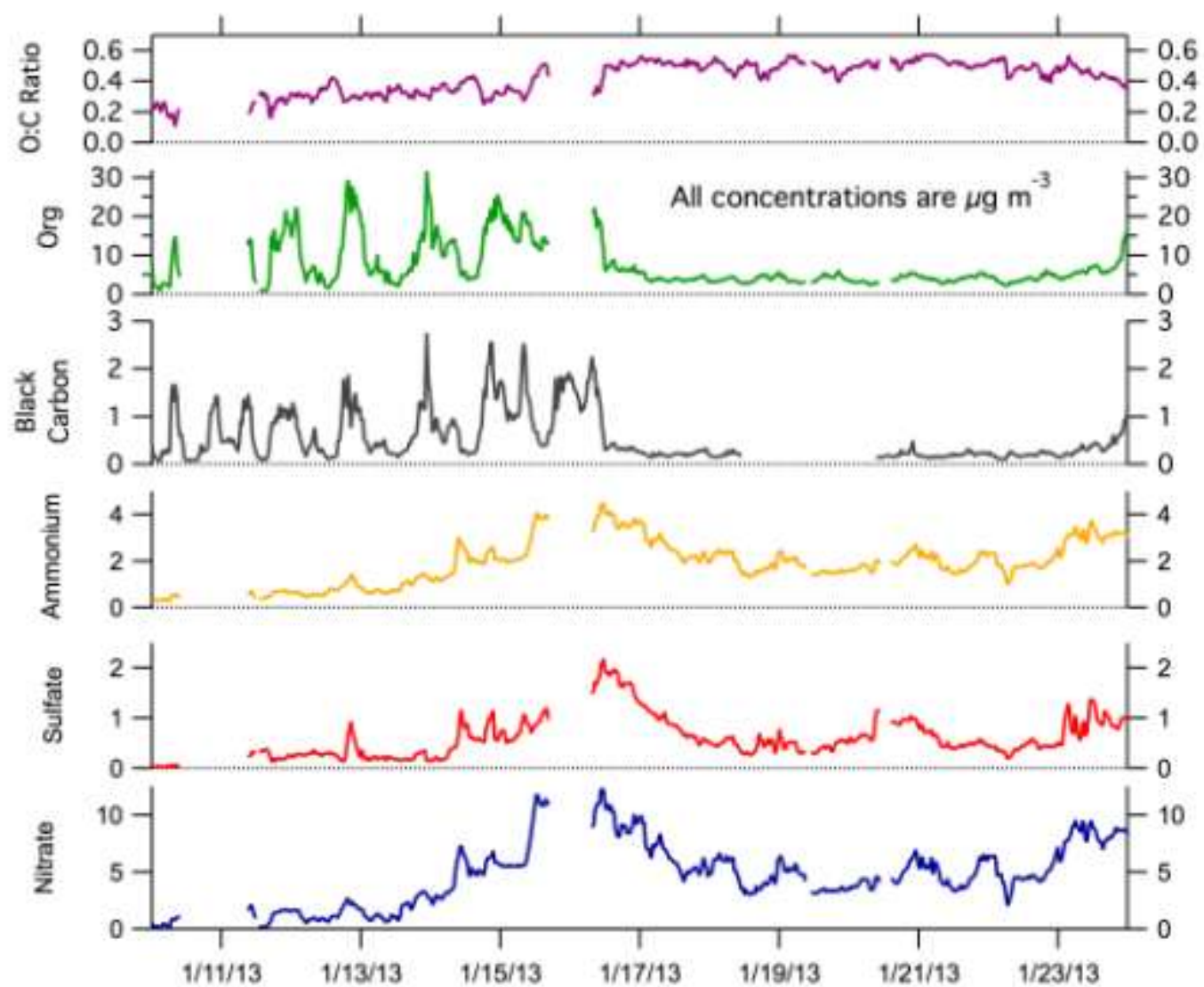

Figure 6. Time series for ammonium $\left(\mathrm{NH}_{4}^{+}\right)$, sulfate $\left(\mathrm{SO}_{4}{ }^{2-}\right)$, nitrate $\left(\mathrm{NO}_{3}{ }^{-}\right)$, and organic material (Org) as measured by the HR-AMS, and the black carbon (BC) concentration from the SP2. All concentrations in $\mu \mathrm{g} \mathrm{m}^{-3}$. Also included is the $\mathrm{O}: \mathrm{C}$ elemental ratio for the organic material (unitless). 

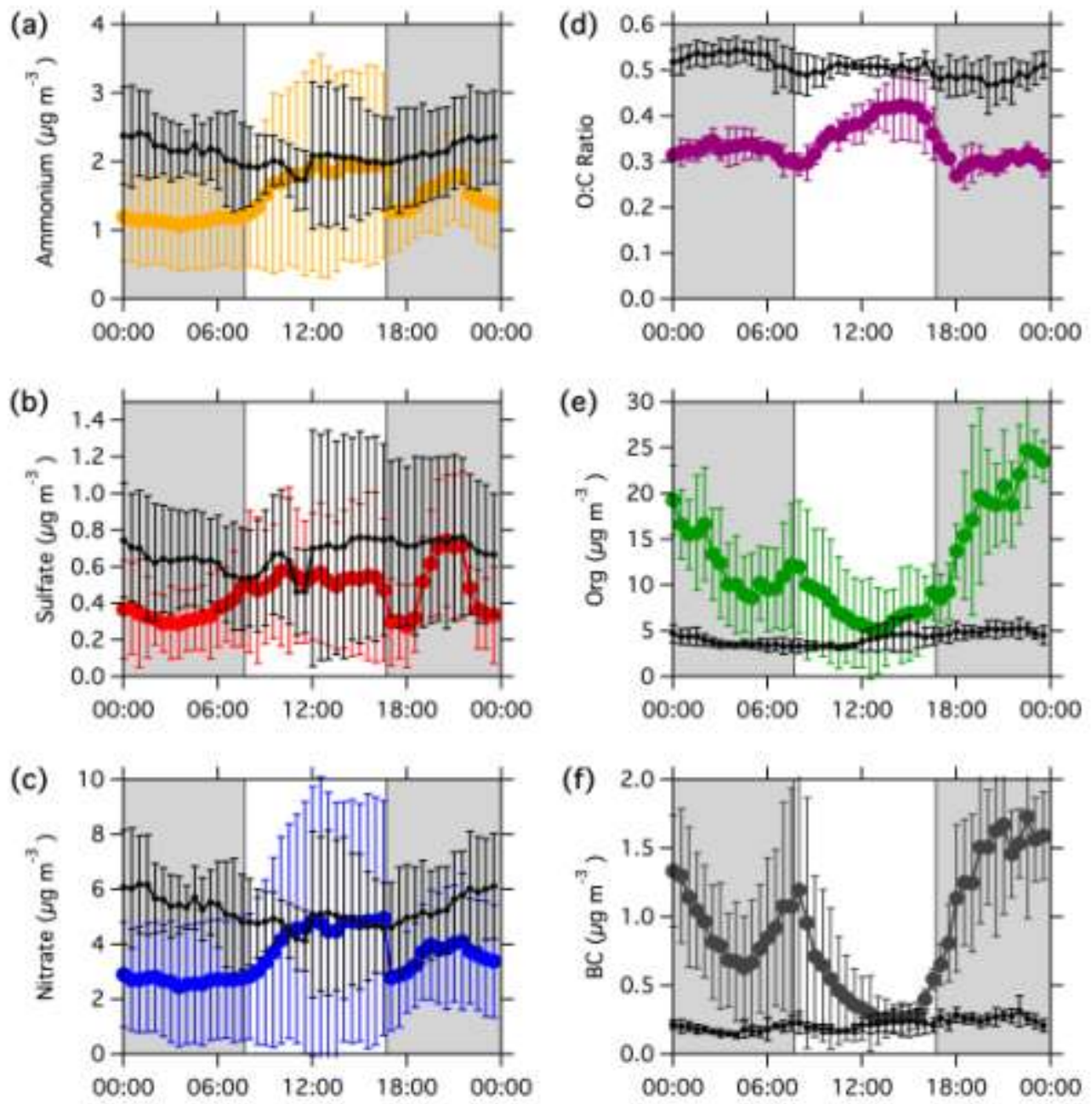

394

Figure 7. Diel cycles for the same parameters shown in Figure 7. In each panel, colored traces represent clear-sky stagnation data (00:00 12 January - 07:00 16 January), and black traces represent the cloudy period (12:00, 16 January - 00:00, 23 January). Vertical bars represent \pm 1 standard deviation of the data to indicate variability. In the clear-sky stagnation data, the increasing day-to-day trend in primary pollutant concentrations is a major contributor to the overall variability. Shaded areas represent nighttime. Note that y-axis scales differ between panels.

The time series reveal that some particulate material components - specifically Org and BC - behave very similarly to the combustion-related trace-gas pollutants shown in Figure 3. Conversely, the major inorganic aerosol components $-\mathrm{NH}_{4}{ }^{+}, \mathrm{SO}_{4}{ }^{2-}$, and $\mathrm{NO}_{3}{ }^{-}-$ exhibit much different temporal patterns. These species do not have the strong diel cycles observed for most pollutants during the clear-sky stagnation period. Nor do their concentrations decrease immediately at the onset of low-level cloud; instead, these species exhibit a much more gradual declining trend beginning on 16 January and continuing steadily until late on 18 January. Even then the concentrations of these inorganic species are significantly elevated above what was observed at the beginning of the stagnation period. 
The diel cycles (Figure 7) confirm the patterns discernable in the time series but also reveal further complexity in the behaviors of $\mathrm{BC}$, Org, and inorganic species during the clear-

414 sky stagnation and cloudy periods. The diel pattern for BC for both periods is again very

415 similar to those of the combustion-dominated trace-gas species in Figure 3. The pattern for

416 Org is also nominally very similar, suggesting that local primary emissions are a significant

417 source of organic $\mathrm{PM}_{2.5}$. Interestingly, the variation in the $\mathrm{O}: \mathrm{C}$ ratio suggests that there is

418 temporal complexity for this component that is not captured in the Org pattern itself. During

419 the clear-sky stagnation period, the O:C ratio is fairly stable near 0.3 during nighttime hours,

420 but during daytime it increase progressively until reaching a peak value above 0.4 in late

421 afternoon. During the cloudy period, the O:C ratio is generally stable throughout the day, but

422 at values that are considerably higher $(\sim 0.5)$ than were observed during the clear-sky

423 stagnation. This indicates that during clear-sky conditions the organic particulate material

424 was relatively more oxidized during daytime hours, but that the oxidation level was even

425 greater under the conditions that prevailed during the cloudy period. The chemical

426 characteristics of the organic aerosol observed during YAWNS will be explored further in a

427 future manuscript.

428 During the clear-sky stagnation period, the diel cycles for inorganic aerosol components were markedly different than for other pollutants. Patterns are similar for the three dominant inorganic species, with some interesting apparent differences between the cloudy and clear periods. Notably, in contrast to Org, which appeared to be dominated by local primary sources during YAWNS, nighttime concentrations of the inorganic secondary pollutants were higher during the cloudy periods than the clear sky period. During the clear period, the inorganic species remain at low concentrations throughout the early morning until sunrise, at which point they each increase gradually for several hours before stabilizing in mid-afternoon. The species then exhibit sharp $\sim 50 \%$ decreases in concentration that coincide with sunset. Another relative maximum for each of the species occurs during evening, but concentrations then rapidly decrease again before midnight. These diel patterns are intriguing, but difficult to interpret given that their variability exists within a day-to-day temporal trend whose magnitude is similar to the range of the diel pattern. pollutants during the cloudy period. Most notably, the species are each consistently observed at the same or higher levels during the cloudy period than at comparable times during the clear-sky stagnation period. Sulfate exhibits a generally level diel profile on average, but 
both $\mathrm{NO}_{3}{ }^{-}$and $\mathrm{NH}_{4}{ }^{+}$have lower mean concentrations during the daytime than at night. For each of the inorganic species, daytime concentrations were similar for the clear-sky stagnation and cloudy periods. However, even during the cloudy period the day-to-day temporal trend for these species contributed significant variability relative to the diel pattern, and so the importance of the observed diel cycles is difficult to assess.

\section{Discussion}

The onset of persistent low-level cloud under regional stagnation conditions during YAWNS led to a sharp decrease in primary pollutant concentrations, particularly those associated with local combustion sources. The primary pollutant concentrations observed throughout the multi-day cloudy period were very similar to those present during daytime under clear-sky stagnation conditions, when the PBL height would increase to $\sim 400 \mathrm{~m}$. Surface winds were similarly low for both the clear and cloudy periods, averaging 0.9 and 1.2 $\mathrm{m} \mathrm{s}^{-1}$, respectively. These results suggest that the degree of mixing between the PBL and the free troposphere above was similar in these two cases; the persistent neutral or slightly unstable conditions present during the cloudy period further supports this conclusion. The degree to which the presence of cloud impacts primary air pollutant levels has significant implications for air quality management during wintertime stagnation episodes.

It is less obvious how the meteorological conditions during YAWNS combined with atmospheric chemical processes led to the observed concentrations for the inorganic secondary $\mathrm{PM}$ components, especially $\mathrm{NO}_{3}{ }^{-}$and $\mathrm{NH}_{4}{ }^{+}$. Understanding this process is important, particularly during cloudy conditions where ammonium nitrate became the major contributor to the PM mass, exceeding even the organics. For example, during the early mornings in the cloudy period, the mean Org concentration was $<5 \mu \mathrm{g} \mathrm{m}^{-3}$, while the sum of $\mathrm{NH}_{4}{ }^{+}$and $\mathrm{NO}_{3}{ }^{-}$was $\sim 8.5 \mu \mathrm{g} \mathrm{m}^{-3}$ (Figure 7). The diel patterns suggest that both dynamics and chemistry may influence the ammonium nitrate levels. Under clear sky conditions, the mean concentrations show an increasing trend for several hours immediately after sunrise, and then decrease sharply again at sunset. The increase is likely due in part to higher residual layer concentrations mixing downward each morning, but the sharpness of the reduction at sunset suggests that near-surface chemical processing could also be a significant contributor. These suggestive results are interesting, but unfortunately the available data are not sufficient to support any conclusions. The possible chemical and dynamic processes influencing the 
476

477

478

480

481

482

483

484

485

486

487

488

489

490

491

492

493

494

495

496

497

498

499

500

501

502

503

504

505

506

ammonium nitrate levels under different meteorological conditions cannot be examined thoroughly without a more complete set of vertically resolved chemical observations.

\section{Conclusions}

The YAWNS data set revealed that previous understanding of air pollution dynamics under regional stagnation conditions was incomplete. While the expected cycles of strong diel variability and elevated nighttime pollution levels were observed during clear sky conditions, the presence of persistent cloud sharply reduced the average surface concentrations of primary pollutants and had more complex impacts on $\mathrm{PM}_{2.5}$ levels. A key question arising from this work is how frequently persistent wintertime cloud episodes occur under regional stagnation conditions, and whether these meteorological events are consistently associated with enhanced dilution of primary pollutants. Certainly periods of persistent cloud like the one observed during YAWNS are not rare in the Yakima valley. Historical meteorological data from the Yakima airport show that similar multi-day episodes characterized by low clouds and near constant temperatures and $\mathrm{RH}$ occur once or twice each winter. Simultaneous $\mathrm{CO}$ and $\mathrm{PM}_{2.5}$ data were available for one such episode, in 2004, and showed that $\mathrm{CO}$ levels were reduced during the episode, while $\mathrm{PM}_{2.5}$ levels were slightly elevated. This result is not dissimilar from what was observed during the YAWNS cloudy period, suggesting that a more thorough study of the effect would be worthwhile.

It may be possible to improve wintertime air quality management by anticipating the likely mitigating impacts on air pollution that seem to be associated with persistent low-level clouds. While meteorological models do not reliably predict such cloudy periods, once they set in such events are clearly identifiable, and in those instances it would beneficial for air quality managers to consider their potential effects. It may be possible in some cases to adjust policy responses targeting primary PM sources on occasions when persistent cloud is accompanied by downward trends in the observed $\mathrm{PM}_{2.5}$ levels. Ultimately though, accurate air quality forecasting during either clear-sky or cloudy stagnation conditions requires accurate modeling of the surface mixing layer. The high-resolution weather forecasting models used by air quality managers do not typically characterize persistent cold air pools satisfactorily, making reliable air quality forecasts challenging. Research studies to better understand the meteorology of persistent cold air pools would be significantly enhanced if the parallel meteorology and air quality research efforts could be merged more effectively. 


\section{Acknowledgments}

508

509

510

511

512

513

514

\section{5}

516

The authors thank personnel from the Yakama Nation, Yakima Valley Community College, and the Yakima Regional Clean Air Authority for their assistance with project planning and operations. Assistance in setting up the field instrumentation was provided by Matthew Erickson, Patrick O'Keeffe, Eric Russell, and Will Wallace. Support for this work was provided by the Washington Department of Ecology. Graham VanderSchelden received fellowship support from the NSF-funded IGERT program "Nitrogen Systems- Policyoriented Integrated Research and Education (NSPIRE)" (Award \#DGE-0903714).

\section{References}

Canagaratna, M.R., Jayne, J.T., Jimenez, J.L., Allan, J.D., Alfarra, M.R., Zhang, Q., Onasch, T.B., Drewnick, F., Coe, H., Middlebrook, A., Delia, A., Williams, L.R., Trimborn, A.M., Northway, M.J., DeCarlo, P.F., Kolb, C.E., Davidovits, P., Worsnop, D.R., 2007. Chemical and microphysical characterization of ambient aerosols with the aerodyne aerosol mass spectrometer. Mass Spectrom. Rev. 26, 185-222. doi:10.1002/mas.20115

Canagaratna, M.R., Jimenez, J.L., Kroll, J.H., Chen, Q., Kessler, S.H., Massoli, P., Hildebrandt Ruiz, L., Fortner, E., Williams, L.R., Wilson, K.R., Surratt, J.D., Donahue, N.M., Jayne, J.T., Worsnop, D.R., 2015. Elemental ratio measurements of organic compounds using aerosol mass spectrometry: characterization, improved calibration, and implications. Atmos Chem Phys 15, 253-272. doi:10.5194/acp-15253-2015

Chachere, C.N., Pu, Z., 2016. Connections Between Cold Air Pools and Mountain Valley Fog Events in Salt Lake City. Pure Appl. Geophys. 173, 3187-3196. doi:10.1007/s00024-016-1316-X

Chazette, P., Couvert, P., Randriamiarisoa, H., Sanak, J., Bonsang, B., Moral, P., Berthier, S., Salanave, S., Toussaint, F., 2005. Three-Dimensional Survey of Pollution During Winter in French Alps Valleys. Atmos. Environ. 39, 1035-1047. doi:10.1016/j.atmosenv.2004.10.014

Chemel, C., Arduini, G., Staquet, C., Largeron, Y., Legain, D., Tzanos, D., Paci, A., 2016. Valley heat deficit as a bulk measure of wintertime particulate air pollution in the Arve River Valley. Atmos. Environ. 128, 208-215. doi:10.1016/j.atmosenv.2015.12.058

Chen, L.-W.A., Watson, J.G., Chow, J.C., Green, M.C., Inouye, D., Dick, K., 2012. Wintertime particulate pollution episodes in an urban valley of the Western US: a case study. Atmos Chem Phys 12, 10051-10064. doi:10.5194/acp-12-10051-2012

DeCarlo, P.F., Kimmel, J.R., Trimborn, A., Northway, M.J., Jayne, J.T., Aiken, A.C., Gonin, M., Fuhrer, K., Horvath, T., Docherty, K.S., Worsnop, D.R., Jimenez, J.L., 2006. Field-Deployable, High-Resolution, Time-of-Flight Aerosol Mass Spectrometer. Anal Chem 78, 8281-8289. doi:10.1021/ac061249n

Droplet Measurement Technologies, 2013. PSI Toolkit for the Single Particle Soot Photometer (SP2).

Grange, S.K., Salmond, J.A., Trompetter, W.J., Davy, P.K., Ancelet, T., 2013. Effect of atmospheric stability on the impact of domestic wood combustion to air quality of a 
small urban township in winter. Atmos. Environ. 70, 28-38. doi:10.1016/j.atmosenv.2012.12.047

Green, M.C., Chow, J.C., Watson, J.G., Dick, K., Inouye, D., 2015. Effects of Snow Cover and Atmospheric Stability on Winter PM2.5 Concentrations in Western U.S. Valleys. J. Appl. Meteorol. Climatol. 54, 1191-1201. doi:10.1175/JAMC-D-14-0191.1

Holmes, H.A., Sriramasamudram, J.K., Pardyjak, E.R., Whiteman, C.D., 2015. Turbulent Fluxes and Pollutant Mixing during Wintertime Air Pollution Episodes in Complex Terrain. Environ. Sci. Technol. 49, 13206-13214. doi:10.1021/acs.est.5b02616

Hughes, J.K., Ross, A.N., Vosper, S.B., Lock, A.P., Jemmett-Smith, B.C., 2015. Assessment of valley cold pools and clouds in a very high-resolution numerical weather prediction model. Geosci Model Dev 8, 3105-3117. doi:10.5194/gmd-8-3105-2015

Kuhns, H., Bohdan, V., Chow, J., Etyemezian, V., Green, M., Herlocker, D., Kohl, S., McGown, M., Ramsdell, J., Stockwell, W., Toole, M., Watson, J., 2003. The Treasure Valley secondary aerosol study I: measurements and equilibrium modeling of inorganic secondary aerosols and precursors for southwestern Idaho. Atmos. Environ. 37, 511-524.

Laborde, M., Schnaiter, M., Linke, C., Saathoff, H., Naumann, K.-H., Moehler, O., Berlenz, S., Wagner, U., Taylor, J.W., Liu, D., Flynn, M., Allan, J.D., Coe, H., Heimerl, K., Dahlkoetter, F., Weinzierl, B., Wollny, A.G., Zanatta, M., Cozic, J., Laj, P., Hitzenberger, R., Schwarz, J.P., Gysel, M., 2012. Single Particle Soot Photometer intercomparison at the AIDA chamber. Atmospheric Meas. Tech. 5, 3077-3097. doi:10.5194/amt-5-3077-2012

Lareau, N.P., Crosman, E., Whiteman, C.D., Horel, J.D., Hoch, S.W., Brown, W.O.J., Horst, T.W., 2013. The Persistent Cold-Air Pool Study. Bull. Am. Meteorol. Soc. 94, 51-63. doi:10.1175/BAMS-D-11-00255.1

Largeron, Y., Staquet, C., 2016. Persistent inversion dynamics and wintertime PM10 air pollution in Alpine valleys. Atmos. Environ. 135, 92-108. doi:10.1016/j.atmosenv.2016.03.045

Lindinger, W., Hansel, A., Jordan, A., 1998. On-line monitoring of volatile organic compounds at pptv levels by means of proton-transfer-reaction mass spectrometry (PTR-MS) medical applications, food control and environmental research. Int. J. Mass Spectrom. Ion Process. 173, 191-241.

Malek, E., Davis, T., Martin, R., Silva, P., 2006. Meteorological and environmental aspects of one of the worst national air pollution episodes (January, 2004) in Logan, Cache Valley, Utah, USA. Atmospheric Res. 79, 108-122. doi:10.1016/j.atmosres.2005.05.003

Monin, A.S., Obukhov, A.M., 1954. Basic laws of turbulent mixing in the surface layer of the atmosphere. Tr Akad Nauk SSSR Geophiz Inst 24, 163-187.

Mwaniki, G.R., Rosenkrance, C., Wallace, H.W., Jobson, B.T., Erickson, M.H., Lamb, B.K., Zalakeviciute, R., VanReken, T.M., 2014. Factors Contributing to Elevated Concentrations of PM2.5 during Wintertime near Boise, Idaho. Atmospheric Pollut. Res. 14, 96-103. doi:10.5094/APR.2014.012

NOAA NOWData, 2013. Yakima Area climatic data.

Pataki, D.E., Tyler, B.J., Peterson, R.E., Nair, A.P., Steenburgh, W.J., Pardyjak, E.R., 2005. Can carbon dioxide be used as a tracer of urban atmospheric transport? J. Geophys. Res.-Atmospheres 110, D15102. doi:10.1029/2004JD005723

Pu, Z., Chachere, C.N., Hoch, S.W., Pardyjak, E., Gultepe, I., 2016. Numerical Prediction of Cold Season Fog Events over Complex Terrain: the Performance of the WRF Model During MATERHORN-Fog and Early Evaluation. Pure Appl. Geophys. 173, 31653186. doi:10.1007/s00024-016-1375-Z 
600

601

602

603

604

605

606

607

608

609

610

611

612

613

614

615

616

617

618

619

620

621

622

623

624

625

626

627

628

629

630

631

632

633

634

635

636

637

638

639

640

641

642

643

644

645

646

647

648

649

Reeves, H.D., Elmore, K.L., Manikin, G.S., Stensrud, D.J., 2011. Assessment of Forecasts during Persistent Valley Cold Pools in the Bonneville Basin by the North American Mesoscale Model. Weather Forecast. 26, 447-467. doi:10.1175/WAF-D-10-05014.1

Reeves, H.D., Stensrud, D.J., 2009. Synoptic-Scale Flow and Valley Cold Pool Evolution in the Western United States. Weather Forecast. 24, 1625-1643. doi:10.1175/2009WAF2222234.1

Schwarz, J.P., Gao, R.S., Fahey, D.W., Thomson, D.S., Watts, L.A., Wilson, J.C., Reeves, J.M., Darbeheshti, M., Baumgardner, D.G., Kok, G.L., Chung, S.H., Schulz, M., Hendricks, J., Lauer, A., Kaercher, B., Slowik, J.G., Rosenlof, K.H., Thompson, T.L., Langford, A.O., Loewenstein, M., Aikin, K.C., 2006. Single-particle measurements of midlatitude black carbon and light-scattering aerosols from the boundary layer to the lower stratosphere. J. Geophys. Res.-Atmospheres 111. doi:10.1029/2006JD007076

Silcox, G.D., Kelly, K.E., Crosman, E.T., Whiteman, C.D., Allen, B.L., 2012. Wintertime PM2.5 concentrations during persistent, multi-day cold-air pools in a mountain valley. Atmos. Environ. 46, 17-24. doi:10.1016/j.atmosenv.2011.10.041

Silva, P., Vawdrey, E., Corbett, M., Erupe, M., 2007. Fine particle concentrations and composition during wintertime inversions in Logan, Utah, USA. Atmos. Environ. 41, 5410-5422. doi:10.1016/j.atmosenv.2007.02.016

Stockwell, W., Kuhns, H., Etyemezian, V., Green, M., Chow, J., Watson, J., 2003. The Treasure Valley secondary aerosol study II: modeling of the formation of inorganic secondary aerosols and precursors for southwestern Idaho. Atmos. Environ. 37, 525534. doi:10.1016/S1352-2310(02)00895-6

Sueper, D., 2010. ToF-AMS Analysis Software [WWW Document]. URL http://cires.colorado.edu/jimenez-group/ToFAMSResources/ToFSoftware/index.html University of Wyoming, 2015. Wyoming Weather Web - Atmospheric Soundings [WWW Document]. URL http://weather.uwyo.edu/upperair/sounding.html (accessed 11.11.15).

Vaisala, Inc., 2010. User's guide: Vaisala boundary layer view software BL-VIEW.

VanderSchelden, G., Jobson, B., de Foy, B., VanReken, T., Herring, C., Kaspari, S., 2017. Influence of Residential Wood Combustion and Vehicle Emissions on Ambient Concentrations of VOCs and PM during the Yakima Wintertime Nitrate Study. J Geophys Res Atmos in press.

Wallace, H.W., Jobson, B.T., Erickson, M.H., McCoskey, J.K., VanReken, T.M., Lamb, B.K., Vaughan, J.K., Hardy, R.J., Cole, J.L., Strachan, S.M., Zhang, W., 2012. Comparison of wintertime CO to NOx ratios to MOVES and MOBILE6.2 on-road emissions inventories. Atmos. Environ. 63, 289-297. doi:10.1016/j.atmosenv.2012.08.062

Washington Department of Ecology, 2014. The Yakima Air Wintertime Nitrate Study (YAWNS): Final Report. Prepared by the Laboratory for Atmospheric Research, Washington State University. URL: http://www.ecy.wa.gov/programs/air/air_monitoring_data/PDFs/Yakima_Air_Winter _Study_Report.pdf (accessed September 16, 2016)

Whiteman, C.D., Bian, X., Zhong, S., 1999. Wintertime Evolution of the Temperature Inversion in the Colorado Plateau Basin. J. Appl. Meteorol. 38, 1103-1117. doi: $10.1175 / 1520-0450$

Whiteman, C.D., Hoch, S.W., Hahnenberger, M., Muschinski, A., Hohreiter, V., Behn, M., Cheon, Y., Zhong, S., Yao, W., Fritts, D., Clements, C.B., Horst, T.W., Brown, W.O.J., Oncley, S.P., 2008. Metcrax 2006: Meteorological Experiments in Arizona's Meteor Crater. Bull. Am. Meteorol. Soc. 89, 1665-1680. doi:10.1175/2008BAMS2574.1 
650

651

652

653

654

655

656

657

658

659

660

661

662

663

664

665

666
Whiteman, C.D., Hoch, S.W., Horel, J.D., Charland, A., 2014. Relationship between particulate air pollution and meteorological variables in Utah's Salt Lake Valley. Atmos. Environ. 94, 742-753. doi:10.1016/j.atmosenv.2014.06.012

Whiteman, C.D., Zhong, S., Shaw, W.J., Hubbe, J.M., Bian, X., Mittelstadt, J., 2001. Cold Pools in the Columbia Basin. Weather Forecast. 16, 432-447. doi:10.1175/15200434(2001)016<0432:CPITCB > 2.0.CO;2

Wolyn, P.G., McKee, T.B., 1989. Deep Stable Layers in the Intermountain Western United States. Mon. Weather Rev. 117, 461-472. doi:10.1175/15200493(1989)117<0461:DSLITI>2.0.CO;2

Zhang, R., Chung, S.H., VanReken, T.M., Lamb, B.K., 2014. Modeling Urban Air Quality during a Wintertime Stagnation Period using the WRF-CMAQ framework.

Zhong, S., Whiteman, C.D., Bian, X., Shaw, W.J., Hubbe, J.M., 2001. Meteorological Processes Affecting the Evolution of a Wintertime Cold Air Pool in the Columbia Basin. Mon. Weather Rev. 129, 2600-2613. doi:10.1175/15200493(2001)129<2600:MPATEO>2.0.CO;2 